\title{
Endothelin Binding to Cultured Calf Adrenal Zona Glomerulosa Cells and Stimulation of Aldosterone Secretion
}

\author{
Eduardo N. Cozza, Celso E. Gomez-Sanchez,* Mark F. Foecking, and Shirley Chiou \\ Department of Internal Medicine, University of South Florida College of Medicine, and James A. Haley Veterans Administration \\ Medical Center, Tampa, Florida 33612
}

\begin{abstract}
Endothelins are a group of potent vasoconstrictors whose structure was deduced from genomic DNA. ET-1 was first isolated from culture supernatants from porcine endothelial cells and ET-3 was identified from a rat DNA library. We report on the binding of ${ }^{125} \mathrm{I}-\mathrm{ET}-1$ to zona glomerulosa cells in culture and on its ability to stimulate aldosterone secretion. Cultured calf adrenal zona glomerulosa cells have saturable, high affinity $\left[K_{d}=1.00 \pm 0.17 \times 10^{-10} \mathrm{M}(\mathrm{SEM})\right]$ receptors which bind ET-1 in a temperature and time dependent manner. Binding was specific and angiotensin II, vasopressin, ANP, BNP, apamin, calcium channel agonists or antagonists did not interact with the receptor. ET-3 displaced ${ }^{125}$ I-ET-1 from the receptor with a relative potency of $0.39 \pm 0.1 \%$ (SEM) that of ET-1.

ET-1 incubated with cultured glomerulosa cells stimulated aldosterone secretion in a dose dependent manner but it was less potent than angiotensin II. ET-3 had $<1 \%$ the relative potency of ET-1 stimulating aldosterone secretion. This data suggest that ET-1 is an independent stimulator of aldosterone secretion and we are speculating that it might be important in those situations, like in malignant hypertension, where endothelial damage might result in increased ET-1 production.
\end{abstract}

\section{Introduction}

The vascular endothelium is the layer of cells in direct contact with the blood. Among its many known diverse functions are: capillary transport, regulation of plasma lipids, participation in the control of hemostasis and modulation of the reactivity of the underlying vascular smooth muscle (1). The endothelium modulates vascular smooth muscle reactivity through vasodilators like endothelium-derived relaxing factor(s) (2) and vasoconstrictors like endothelium-derived contracting factor(s) (3). Endothelin, an endothelium-dependent contracting factor first isolated from porcine endothelial cells in culture, is a 21 aminoacid peptide with two disulphide bonds (4).

Address reprint requests to Dr. Gomez-Sanchez, Department of Medicine, University of South Florida College of Medicine, 13000 Bruce B. Downs Blvd., VAH $111 \mathrm{M}$, Tampa, FL 33612.

Received for publication 7 April 1989 and in revised form 17 May 1989.

The Journal of Clinical Investigation, Inc.

Volume 84, September 1989, 1032-1035
The porcine gene has been cloned and the 203 aminoacid preproendothelin has been shown to be highly homologous with the 212 aminoacid human preproendothelin and the portion of the molecule corresponding to endothelin is identical in man and pig (5). The nucleotide sequence using a rat library predicted a 21 residue rat endothelin with 15 aminoacids identical and 3 aminoacids chemically similar to those in the porcine/human endothelin peptide (6). Three distinct human-endothelin related genes have been identified in a human genomic DNA library encoding for three peptides (7) whose structure corresponds to: (a) "classical" endothelin (ET-1), "rat" endothelin (ET-3) and a new endothelin which differs in two aminoacids from ET-1 (ET-2). Furthermore, porcine and rat cDNA libraries also encoded for the same peptides (7). ET-1 is more potent as a vasoconstrictor than angiotensin II in isolated vascular preparations (4). The vasoconstrictor/pressor properties of ET-3 are less than those of ET-1 (6).

Intravenous ET-1 administration to anesthetized or conscious dogs results in elevation of plasma renin activity and aldosterone $(8,9)$. The stimulation of aldosterone secretion could either be indirect through renin stimulation of aldosterone secretion or by direct action of ET-1 in the adrenal zona glomerulosa. We studied the possibility that the adrenal zona glomerulosa had receptors for ET-1 and that endothelins could directly stimulate aldosterone secretion.

\section{Methods}

ET-1 was purchased from Peninsula Laboratories Inc. (Belmont, CA). ET-3 was obtained from Peptides International (Louisville, KY). The endothelins were biologically active as tested by their ability to raise the blood pressure in anesthetized rats. Endothelins were dissolved in $0.1 \%$ acetic acid and stored in $10 \mu \mathrm{l}$ containing $5 \mu \mathrm{g}$ peptide at $-70^{\circ} \mathrm{C}$ in silanized glass tubes.

Iodination of ET-1. ET-1 was iodinated by placing $20 \mu \mathrm{l}$ of $0.5 \mathrm{M}$ sodium phosphate buffer $\mathrm{pH} 7.0$ into a tube containing the endothelin, adding $10 \mu \mathrm{l}$ of sodium ${ }^{125} \mathrm{I}(1 \mathrm{mCi})$ and $10 \mu \mathrm{l}$ of freshly prepared chloramine $T(0.5 \mathrm{mg} / \mathrm{ml}$ in the phosphate buffer). The reaction proceeded for $30 \mathrm{~s}$ and was stopped by adding $10 \mu \mathrm{l}$ of cysteine $(2.3 \mathrm{mg} / \mathrm{ml}$ in phosphate buffer). After diluting to $100 \mu l$ with water, the sample was injected into a column system consisting of a $0.5 \times 25 \mathrm{~cm}$ HPLC column (end-capped Chromosorb $\mathrm{C}-18,5 \mu \mathrm{m}$ ) fitted with a precolumn that contained end-capped pellicular media (Pell C18; Whatman Co., Clifton, NJ). A three-way valve was placed between the precolumn and column and was left open to waste while the precolumn was eluted for $10 \mathrm{~min}$ at a rate of $1 \mathrm{ml} / \mathrm{min}$ with acetonitrile 20 and $80 \%$ trifluoroacetic acid (TFA) $0.1 \%$. This step eliminated the free iodide and mini-

1. Abbreviation used in this paper: ET, endothelin. 
mized contamination of the analytical column. The valve was then closed and a gradient started from 20 to $60 \%$ acetonitrile with the TFA aqueous phase. $1-\mathrm{ml}$ aliquots were collected and counted. Two major peaks were found; one eluted at $47 \mathrm{ml}$ and a second at $50 \mathrm{ml}$ in a proportion of 3 to 1 . Iodination at $\mathrm{pH} 8.5$ produced a ratio of 1 to 3 . The first peak bound significantly better to the receptors than the second peak and was used in these studies. The specific activity of ${ }^{125} \mathrm{I}-\mathrm{ET}-1 \mathrm{l}(600-1,100 \mathrm{Ci} / \mathrm{mmol})$ was measured as described by Calvo et al. (10).

Culture of adrenal zona glomerulosa cells. Calf adrenal glands were obtained from a local abattoir and trimmed clean of fat and adhering tissue under sterile conditions. The cells were dispersed and cultured as described by Crivello et al. (11) with modifications as previously described (12). The cells were plated in either 24-well plates $(200,000 /$ well; Costar, Cambridge, MA) or 6-well plates $(1,000,000 /$ well) and incubated at $37^{\circ} \mathrm{C}$ in a $5 \% \mathrm{CO}_{2}$ air environment. The medium was changed $24 \mathrm{~h}$ later and the cells were incubated for 3-5 $\mathrm{d}$ with medium containing $12 \mathrm{mM}$ potassium before being used for stimulation or receptor binding studies.

Binding of ${ }^{125} I-E T-1$ to adrenal cells. Confluent adrenal cells from 6-well plates were washed with culture media and incubated for $60 \mathrm{~min}$ at $37^{\circ} \mathrm{C}$ with $60 \mathrm{pmol}$ of ${ }^{125} \mathrm{I}$-ET-1 plus increasing concentrations of unlabeled ET-1. Nonspecific binding was determined by incubating with $10^{-7} \mathrm{M}$ ET-1. The incubation media was Ham F12 with $0.1 \%$ BSA, pepstatin $10 \mu \mathrm{g} / \mathrm{ml}$, and bacitracin $100 \mu \mathrm{g} / \mathrm{ml}$. At the end of the incubation, the media was aspirated and the cells washed five times with ice-cold HBSS containing $0.1 \%$ BSA. Two $0.5-\mathrm{ml}$ aliquots of 0.5 $\mathrm{N} \mathrm{NaOH}$ were added and the dispersed tissue aspirated and transferred to a tube for counting using a Tracor Gamma Counter. A similar study was done with increasing concentrations of ${ }^{125}$ I-ET-1 to study the affinity of the iodinated moiety for the receptors. Binding kinetics were calculated using Scatchard's plot using a computer program.

The association constant was studied by measuring the binding of 60 pmol ${ }^{125}$ I-ET-1 to the cells during the linear portion of binding. Dissociation of ${ }^{125}$ I-ET-1 from the receptor was studied by preincubating adrenal cells with $60 \mathrm{pmol}$ of ${ }^{125} \mathrm{I}-\mathrm{ET}-1$ for $60 \mathrm{~min}$ at $37^{\circ} \mathrm{C}$, at the end of which ET $-1 \quad 10^{-7} \mathrm{M}$ was added. At various time periods the cells were washed and counted as above.

The specificity of binding was studied by testing the ability of several peptides, ET-3, angiotensin II, ACTH, apamin, vasopressin, atrial natriuretic factor, and brain natriuretic factor, and calcium channel active agents, BAY K 8644, verapamil, nifedipine, and diltiazem, at concentrations of $10^{-8}$ to $10^{-6} \mathrm{M}$ to displace ${ }^{125} \mathrm{I}$-ET-1 from the adrenal receptor.

Incubation of adrenal zona glomerulosa cells with endothelins. Cells grown for 3-4 d in 24-well plates were incubated with increasing concentrations of endothelin for $2 \mathrm{~h}$ at $37^{\circ} \mathrm{C}$ in a $5 \% \mathrm{CO}_{2}$ atmosphere. The incubation media contained $4 \mathrm{mM}$ potassium. A control incubation using angiotensin II was done simultaneously. Aldosterone secretion was measured by direct RIA using a monoclonal antibody (13). Statistical analysis of the differences between groups were done using ANOVA.

\section{Results}

Binding of ${ }^{125} \mathrm{I}-\mathrm{ET}-1$ at $37^{\circ} \mathrm{C}$ to zona glomerulosa adrenal cells in culture was time dependent and reached an apparent equilibrium at $60 \mathrm{~min}$. All subsequent experiments were done after $60 \mathrm{~min}$ of incubation. Nonspecific binding was usually around $10 \%$ of bound radioactivity. Binding of ET- 1 was saturable and Scatchard analysis revealed the presence of a single class of high-affinity binding sites with an apparent dissociation constant $\left(K_{\mathrm{d}}\right)$ of $1.00 \pm 0.17 \times 10^{-10} \mathrm{M}($ mean \pm SEM, $n=8)$ and a maximal binding capacity $\left(B_{\max }\right)$ of $52,424 \pm 7,320$ receptors/ cell (Fig. 1). The $K_{\mathrm{d}}$ and $B_{\max }$ of ${ }^{125} \mathrm{I}-\mathrm{ET}-1$ and unlabeled ET-1 were similar. The $K_{\mathrm{a}}$ was also measured from data shown in

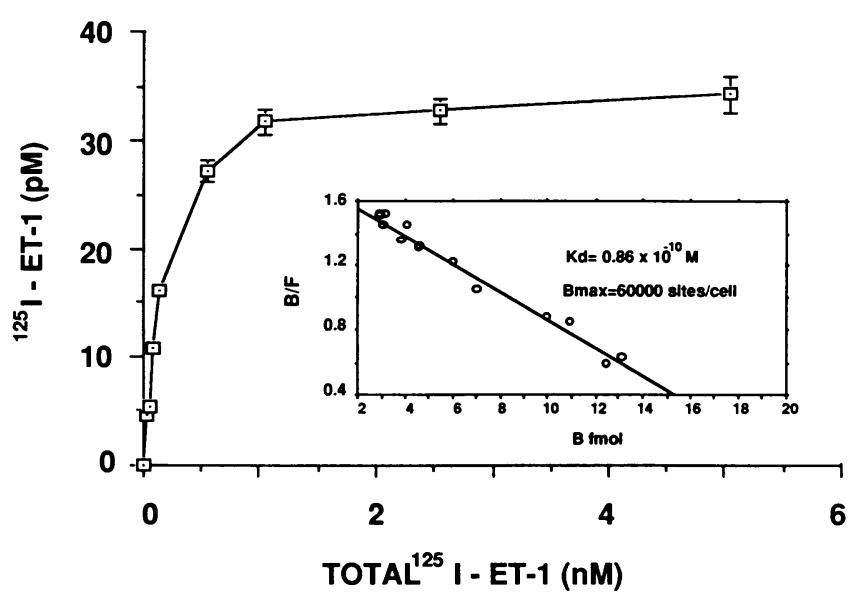

Figure 1. Binding of ${ }^{125}$ I-ET-1 to cultured calf adrenal zona glomerulosa cells. (Inset) Scatchard plot of binding data of a representative experiment $(n=8)$.

Fig. 2 using the formula: $K_{\mathrm{a}}=\frac{k_{\mathrm{a}}}{k_{\mathrm{d}}}=\frac{2.89 \times 10^{6} \mathrm{M}^{-1} \cdot \mathrm{s}^{-1}}{1.26 \times 10^{-4} \mathrm{~s}^{-1}}=2.3$ $\times 10^{10} \mathrm{M}^{-1}$ the result of which is very similar to the one calculated from the $K_{\mathrm{d}}\left(K_{\mathrm{a}}=1.16 \times 10^{10} \mathrm{M}^{-1}\right)$.

Binding of ET-1 to the receptor was specific and angiotensin II, ACTH, vasopressin, apamin, atrial natriuretic factor and brain natriuretic factor did not displace ${ }^{125}$ I-ET-1 from the receptor. Neither the calcium channel agonist BAY K 8644 or calcium channel antagonists verapamil, diltiazem, and nifedipine at a concentration of $10^{-6} \mathrm{M}$ displace ${ }^{125} \mathrm{I}-\mathrm{ET}-1$ from the receptor. ET-3 displacement of ${ }^{125}$ I-ET-1 is shown in Fig. 3. The relative potency from data (at $50 \%$ displacement of the tracer) of three different experiments indicated the ET-3 is only $0.39 \pm 0.1 \%$ (SEM) as potent as ET-1.

ET-1 stimulated aldosterone secretion in a dose-dependent fashion (Fig. 4). Angiotensin II $\left(10^{-9} \mathrm{M}\right)$ is a more powerful stimulator of aldosterone secretion. As predicted from their relative binding activity to the receptor, ET-3 was significantly less potent than ET-1 ( $<1 \%$ by extrapolation).

\section{Discussion}

ET-1 binding kinetics to cultured zona glomerulosa cells were very similar to that of vascular smooth muscle cells but the number of receptors per cell was about five times greater in adrenal cells than vascular smooth muscle (14). In isolated arterial strips, ET-1 (4) has been reported to produce a vasoconstrictive effect dependent upon the presence of extracellular $\mathrm{Ca}^{2+}$ and attenuated by $\mathrm{Ca}^{2+}$ antagonists. The structures of

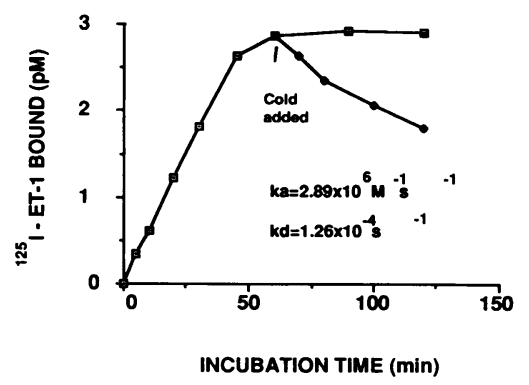

Figure 2. Timed specific binding of ${ }^{125} \mathrm{I}$-ET1 to cultured calf zona glomerulosa cells followed by dissociation after the addition of $10^{-7}$ ET- 1 . 


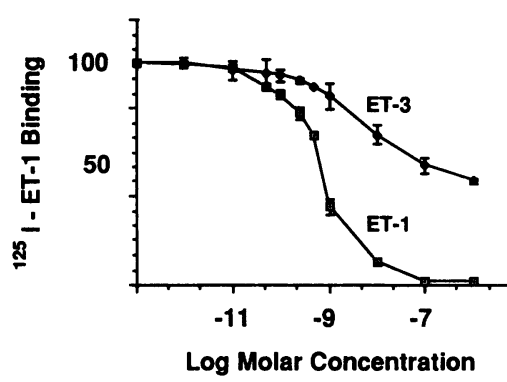

Figure 3. Displacement of ${ }^{125}$ I-ET-1 by unlabeled ET-1 and ET-3 from the adrenal receptor. A representative figure is shown $(n=3)$.

endothelins resemble other peptides which interact with membrane ion-conducting channels (4). The endothelin binding site of calf zona glomerulosa cells is different from those of the L-type $\mathrm{Ca}^{2+}$ channel agonist BAY K 8644 or the antagonists nifedipine, verapamil, or diltiazem, since none of these agents had any effect on ${ }^{125} \mathrm{I}$-ET-1 binding. It has also been reported that ET-1 fails to displace radioactively labeled calcium antagonists from the $\mathrm{Ca}^{2+}$ channels (15) and that ET-1 has different vasoconstrictive properties in vitro than the Ltype $\mathrm{Ca}^{2+}$ channel agonist BAY K 8644 (16). The evidence indicates that the mechanism of action of ET-1 does not involve binding to the $\mathrm{Ca}^{2+}$ channel. ET-1 stimulates metabolism of inositol phosphates and mobilization of intracellular $\mathrm{Ca}^{2+}$ stores (17-19) resulting in a transient activation of the $\mathrm{Ca}^{2+}$ sensitive $\mathrm{K}^{+}$channel and provoking hyperpolarization of the membrane (20). This is followed by a sustained depolarization that seems to be due to the opening of a nonspecific cation channel permeable to $\mathrm{Ca}^{2+}$ and $\mathrm{Mg}^{2+}$ which then activates the L-type $\mathrm{Ca}^{2+}$ channels (20). This indirect activation of the $\mathrm{L}$ type $\mathrm{Ca}^{2+}$ channels probably mediate ET-1 action.

ET-3 was found to be significantly less potent than ET-1 in producing vasoconstriction (6) and in stimulating aldosterone secretion.

A subset of patients with malignant hypertension have increased plasma renin activity and aldosterone secretion (21), as well as prominent alterations in their vascular endothelium (22) that might result in an enhanced production of ET-1 (4). Treatment of malignant hypertension is associated with a dissociation between an early normalization of plasma renin activity and a persistent elevation of aldosterone secretion (21), thought to be due to either chronic adrenal stimulation with

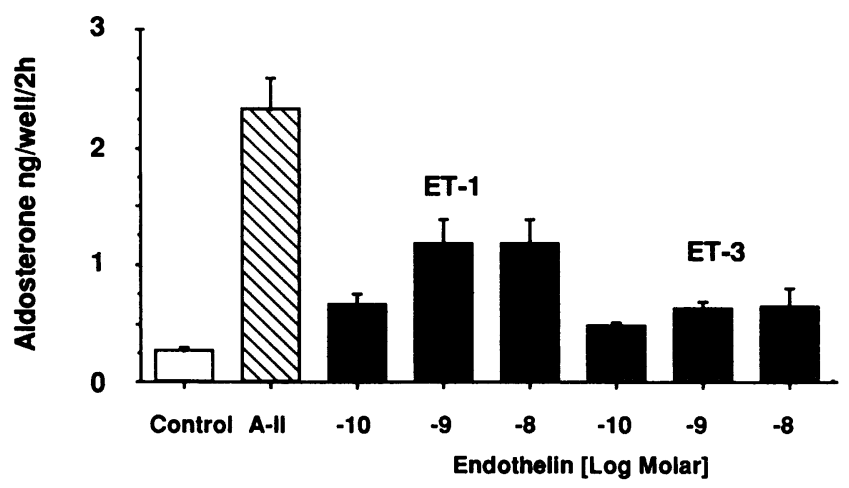

Figure 4. Stimulation by angiotensin II, ET-1 and ET-3 of aldosterone secretion by calf zona glomerulosa cells in culture. A representative experiment is shown $(n=3)$. Each point is the mean \pm SEM of four wells. The increase of aldosterone secretion was significant $(P<0.05)$ with all doses.

angiotensin II or the production of an additional factor(s) which continues to stimulate aldosterone secretion after angiotensin II production is normalized (21). Our results indicate that ET-1 is an independent stimulator of aldosterone secretion and we are speculating that ET-1 might participate in the abnormal regulation of aldosterone secretion in malignant hypertension where vascular endothelial damage might result in an increase ET-1 gene expression (4), but this remains to be studied.

Autoradiographic studies with ${ }^{125}$ I-ET-1 have shown that binding occurs in the zona glomerulosa and adrenal medulla of human, pig, and rat adrenals (23). It is not yet known if ET-1 is a circulating or paracrine agent, nor is its role in the regulation of aldosterone secretion in vivo clear.

\section{Acknowledgments}

These studies were supported by Medical Research Funds of the Veterans Administration and grants from the National Institutes of Health (HL-27255 and HL-27737).

\section{References}

1. Peach, M. J., and A. L. Loeb. 1987. Changes in vascular endothelium and its function in systemic arterial hypertension. Am. J. Cardiol. 60:110I-115I.

2. Furchgott, R. F., and J. V. Zawadzki. 1980. The obligatory role of endothelial cells in relaxation of arterial smooth muscle by acetylcholine. Nature (Lond.). 288:373-376.

3. Hickey, K. A., G. Rubanyi, R. J. Paul, and R. F. Highsmith. 1985. Characterization of a coronary vasoconstrictor produced by cultured endothelial cells. Am. J. Physiol. 248:C550-C556.

4. Yanagisawa, M., H. Kurihara, S. Kimura, Y. Tomobe, M. Kobayashi, Y. Mitsui, Y. Yazaki, K. Goto, and T. Masaki. 1988. A novel potent vasoconstrictor peptide produced by vascular endothelial cells. Nature (Lond.). 332:411-415.

5. Itoh, Y., M. Yanagisawa, S. Ohkubo, C. Kimura, m T. Kosaka, A. Inoue, N. Ishida, Y. Mitsui, H. Onda, M. Fujino, and T. Masaki. 1988. Cloning and sequence analysis of cDNA encoding the precursor of human endothelium-derived vasoconstrictor peptide, endothelin: identity of human and porcine endothelin. FEBS (Fed. Eur. Biochem. Soc.) Lett. 231:440-444.

6. Yanagisawa, M., A. Inoue, T. Ishikawa, Y. Kasuya, S. Kimura, S.-I. Kumagaye, K. Nakajima, T. X. Watanabe, S. Sakakibara, K. Goto, and T. Masaki. 1988. Primary structure, synthesis, and biological activity of rat endothelin, an endothelium-derived vasoconstrictor peptide. Proc. Natl. Acad. Sci. USA. 85:6964-6967.

7. Inoue, A., M. Yanagisawa, S. Kimura, Y. Kasuya, T. Miyauchi, K. Goto, and T. Masaki. 1989. The human endothelin family: three structurally and pharmacologically distinct isopeptides predicted by three separate genes. Proc. Natl. Acad. Sci. 86:2863-2867.

8. Miller, W. L., M. M. Redfield, and J. C. Burnett. 1989. Integrated cardiac, renal, and endocrine actions of endothelin. J. Clin. Invest. 83:317-320.

9. Goetz, K. L., B. C. Wang, J. B. Madwed, J. L. Zhu, and R. J. Leadley. 1988. Cardiovascular, renal, and endocrine response to intravenous endothelin in conscious dogs. Am. J. Physiol. 255:R1064R1068.

10. Calvo, J. C., J. P. Radicella, and E. H. Charreau. 1983. Measurement of specific radioactivities in labelled hormones by self-displacement analysis. Biochem. J. 212:259-264.

11. Crivello, J. F., P. J. Hornsby, and G. N. Gill. 1982. Metyrapone and antioxidants are required to maintain aldosterone synthesis by cultured bovine adrenocortical zona glomerulosa cells. Endocrinology. 111:469-479. 
12. Cozza, E. N., M. C. Vila, C. E. Gomez-Sanchez, and R. V. Farese. 1988. ACTH stimulates turnover of the phosphatidylinositolglycan. Biochem. Biophys. Res. Commun. 157:585-589.

13. Gomez-Sanchez, C. E., M. F. Foecking, M. W. Ferris, M. R. Chavarri, L. Uribe, and E. P. Gomez-Sanchez. 1987. The production of monoclonal antibodies against aldosterone. Steroids. 49:581-587.

14. Hirata, Y., H. Yoshimi, S. Takata, T. X. Watanabe, S. Kumagai, K. Nakajima, and S. Sakakibara. 1988. Cellular mechanism of action by a novel vasoconstrictor endothelin in cultured rat vascular smooth muscle cells. Biochem. Biophys. Res. Commun. 154:868-875.

15. Gu, X. H., J. J. Liu, J. S. Dillon, and W. G. Nayler. 1989. The failure of endothelin to displace bound, radioactively labelled, calcium antagonists (PN 200/110, D888 and diltiazem). Br. J. Pharmacol. 96:262-264.

16. Auguet, M., S. Delaflotte, P. E. Chabrier, E. Pirotzky, F. Clostre, and P. Braquet. 1988. Endothelin and $\mathrm{Ca}++$ agonist BAY K 8644: different vasoconstrictive properties. Biochem. Biophys. Res. Commun. 156:186-192.

17. Miasiro, N., H. Yamamoto, H. Kanaide, and M. Nakamura. 1988. Does endothelin mobilize calcium from intracellular store sites in rat aortic vacular smooth muscle cells in primary culture? Biochem. Biophys. Res. Commun. 156:312-317.
18. Marsden, P. A., N. R. Vanthuluri, B. M. Brenner, B. J. Ballermann, and T. A. Brock. 1989. Endothelin action on vascular smooth muscle involves inositol trisphosphate and calcium mobilization. Biochem. Biophys. Res. Commun. 158:86-93.

19. Sugiura, M., T. Inagami, G. M. T. Hare, and J. A. Johns. 1989. Endothelin action: inhibition by a protein kinase $C$ inhibitor and involvement of phosphoinositols. Biochem. Biophys. Res. Commun. 158:170-176.

20. Van Renterghem, C., P. Vigne, J. Barhanin, A. Schmid-Alliana, C. Frelin, and M. Lazdunski. 1988. Molecular mechanism of action of the vasoconstrictor peptide endothelin. Biochem. Biophys. Res. Commun. 157:977-985.

21. McAllister, R. G., C. W. Van Way, K. Dayani, W. J. Anderson, E. Temple, A. M. Michelakis, W. S. Coppage, and J. A. Oates. 1971. Malignant hypertension: effects of therapy on renin and aldosterone. Circ. Res. 28:II-160-II-174.

22. Huttner, I., and G. Gabbiani. 1983. Vascular endothelium in hypertension. In Hypertension. J. Genest, O. Kuchel, P. Hamet, and M. Cantin, editors. McGraw-Hill Book Co. New York. 473-488.

23. Davenport, A. P., D. J. Nunez, J. A. Hall, A. J. Kaumann, and M. J. Brown. 1989. Autoradiographical localization of binding sites for porcine [ $\left.{ }^{125} \mathrm{I}\right]$ endothelin-1 in humans, pigs, and rats: functional relevance in humans. J. Cardiovasc. Pharmacol. 13(Suppl. 5):S166-S170. 